\title{
A study of the effects of pinealectomy on intestinal cell proliferation in infant newborn rats ${ }^{1}$
}

\author{
Estudo dos efeitos da pinealectomia na proliferação celular intestinal \\ de ratos recém-nascido
}

\author{
Marcelo Belini Dalio ${ }^{2}$, Luis Fernando Haikel Júnior², Renato Belini Dalio ${ }^{2}$, André Pera Marques Pinto², Júlio César \\ Fernandes da Silva ${ }^{3}$, Marcelo Vinícius Oliveira Vespúcio ${ }^{3}$, Marco Aurélio Guimarães ${ }^{4}$, Sérgio Britto Garcia ${ }^{4}$ \\ 1. Department of Pathology, Ribeirão Preto School of Medicine (FMRP-USP). São Paulo, Brazil. \\ 2. MD, Resident University Hospital (FMRP-USP). \\ 3. MD, PhD fellow in Post-Graduation Program in Pathology (FMRP-USP). \\ 4. MD, PhD, Assistant Professor (FMRP-USP).
}

\begin{abstract}
Purpose: Study the proliferation rate of jejunum and large intestine crypt epithelial cells, in rats pinealectomized immediately after borning. Methods: Twenty-four male Wistar rats were distributed into two groups: Acute group ( $\mathrm{n}=12)$ and Chronic group $(n=12)$. Six animals of each group were operated for removal of the pineal gland (pinealectomy-PnX), and other six were controls (sham pinealectomy-C). Animals from acute and chronic group were sacrificed 15 and 90 days after the surgery, respectively. Results: In acute group, pinealectomy of new-born rats has not caused significant alteration in cell proliferation $(\mathrm{PnX}=58,77 \pm 1,77$ and $\mathrm{C}=60,88 \pm 1,10$ in the descending colon/ $\mathrm{PnX}=31,56 \pm 0,45$ and $\mathrm{C}=31,73 \pm 0,47$ in the proximal jejunum) and in crypt cell population $(\mathrm{PnX}=24,92 \pm 4,82$ and $\mathrm{C}=23,60 \pm 2,48$ in the descending colon/ $\mathrm{PnX}=39,92 \pm 3,49$ and $\mathrm{C}=44,32 \pm 5,56$ in the proximal jejunum). However, in chronic group there was an uprising crypt cell production per crypt in the proximal jejunum $(\mathrm{PnX}=57,54 \pm 2,19$ and $\mathrm{C}=47,19 \pm 7,3)$ and in the descending colon ( $\mathrm{PnX}=37,78 \pm 2,22$ and $\mathrm{C}=17,92 \pm 2,28)$. Conclusion: As the increase of intestinal crypts epithelial cells in chronic group is a carcinogenesis predetermining factor, the understanding of the interaction between pineal gland and this event has great importance.
\end{abstract}

Key words: Pineal Gland. Intestine, Small. Instestine, Large. Infant, Newborn. Rats.

\section{RESUMO}

Objetivo: Estudar a taxa de proliferação celular no jejuno e nas células epiteliais das criptas do intestino grosso em ratos pinealectomizados imediatamente após o nascimento. Métodos: 24 ratos machos Wistar foram divididos em dois grupos. Grupo agudo (n=12) e Grupo Crônico (n=12). Seis animais de cada grupo foram operados para remover-se a glândula pineal (Pinealectomia-PnX), e outros seis animais foram controle (sham pinealectomia-C). Os animais de ambos os grupos foram sacrificados 15 e 90 dias após a cirurgia, respectivamente. Resultados: No grupo agudo, a pinealectomia dos ratos não causou alterações significativas na proliferação celular $(\mathrm{PnX}=58,77 \pm 1,77$ e $\mathrm{C}=60,88 \pm 1,10$ no cólon descendente / $\mathrm{PnX}=31,56 \pm 0,45$ e $C=31,73 \pm 0,47$ no jejuno proximal) e na população celular de criptas ( $\mathrm{PnX}=24,92 \pm 4,82$ e $\mathrm{C}=23,60 \pm 2,48$ no cólon descendente / $\mathrm{PnX}=39,92 \pm 3,49$ e $\mathrm{C}=44,32 \pm 5,56$ no jejuno proximal). Contudo, no grupo crônico houve aumento na proliferação celular das criptas no jejuno proximal $(\mathrm{PnX}=57,54 \pm 2,19$ e $\mathrm{C}=47,19 \pm 7,3)$, e no cólon descendente $(\mathrm{PnX}=37,78 \pm 2,22$ e $\mathrm{C}=17,92 \pm 2,28)$. Conclusão: Como o aumento epitelial celular das criptas intestinais no grupo crônico pode ser avaliado como fator predeterminante da carcinogênese, faz-se necessário o conhecimento da interação entre esta glândula e este evento.

Descritores: Glândula Pineal. Intestino Delgado. Intestino Grosso. Recém-Nascido. Ratos.

\section{Introduction}

The pineal gland has an important role on the control of the circadian rhythm and it is thought that it influences other general physiological processes such as hormonal controls ${ }^{1}$. There is growing evidence that the pineal gland also plays an important role on the control of cell proliferation. Callaghan et al ${ }^{2}$, have observed that pinealectomy in adult rats causes a significant rise in the mitotic rate of the epithelial cells within the crypts of the small bowel, in a period from two to six months after the surgery. In the colonic crypts this hiperproliferative effect use to be smaller than in the small bowel. Mechanism that explains this effect is poorly known. Our aim was to study the proliferation rate of jejunum and large intestine crypt epithelial cells, in rats pinealectomized immediately after borning. 


\section{Methods}

Twenty-four male Wistar rats were distributed into two groups: Acute group $(n=12)$ and Chronic group $(n=12)$. The animals were maintained at approximately $22^{\circ} \mathrm{C}$ and in $12: 12-$ $\mathrm{h}$ light-dark cycle, and supplied with tap water ad libitum and comertial food. One day after borning the animals were assigned randomly into two groups and anaesthetized with Nembutal. The acute group animals $(n=12)$ were sacrificed 15 days after the surgery. Six animals of this group were operated for the removal of the pineal gland (pinealectomy), and other six were controls (Sham pinealectomy). The pinealectomy was performed via a scalp incision, a disc of bone was removed from the cranium over the lambdoid suture to expose the superior sagittal sinus, which was ligated and divided. The pineal gland was removed in a manner similar to described ${ }^{3}$. Bleeding was controlled by gelfoam (The Upkohn Co. Kalamazoo, Michigan, U.S.A) and the scalp was closed. The removed pineal gland was fixed in $10 \%$ phosphate-buffered formalin. Paraffin sections of $5 \mathrm{~m}$ thickness were stained with $1 \%$ toluidine blue and examined microscopically to confirm pinealectomy in all groups. The other rats were operated for a simulated surgery and did not have their gland extracted. The same experimental design was adopted to chronic group, with two subgroups: 1) Pinealectomized rats (CP) and 2) Control rats (CC). The same procedure as for pinealectomy was followed, including ligation of the superior sagittal sinus, except that the pineal gland was not removed. On the right date, the rats were killed with ether anesthesia, according to the metaphases blocking method with vincristine sulfated described later. The samples of colon and jejunum were embedded in paraffin. Five ìm thick sections oriented to show the long axis of the colon crypt were stained Hematoxylin-Eosin. Cell counts were made with a 40x objective and 10x ocular. The crypt cell population (CCP) was calculated as twice the hemicrypt population added to mitoses population. Thirty different crypts of each animal were utilized to the cell counting. The mitotic index (MI) of crypts was calculated by the expression:

$$
\mathrm{MI}=\frac{\mathrm{Nm} \times \mathrm{Tf}}{\mathrm{Nt}}
$$

Where $\mathrm{Nm}=$ number of mitoses (metaphases), $\mathrm{Nt}=$ total crypt cell population and $\mathrm{Tf}=$ Tannock's factor ${ }^{4}$. The mean MI value was plotted against time after vincristine injection. The resulting metaphases arrest line was fitted by least squares linear regression and the slope of the line multiplied by 60 minutes represented the cell production per crypt. This was expressed as cells /1000crypt cells/ hour. The results are reported as means \pm SEM (Standard Error Mean), with the level of significance set at $5 \%$.

\section{Results}

We observed that there was no alteration in proliferation of mucosa epithelium cell of pinealectomized animals from the acute group (15 days) when compared to the control groups, in colon (Figure 1) as much as jejunum (Figure 2).
Chronic group (90 days) There was clear increase of cell proliferation rate in the pinealectomized animals, compared to control groups, in colon (Figure 3) as much as in jejunum (Figure 4).

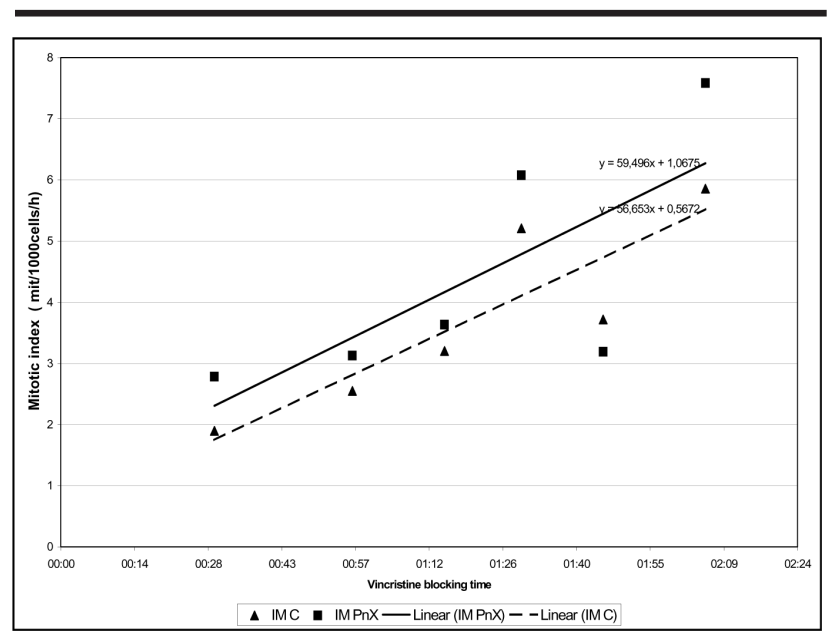

FIGURE 1 - Acute group mitotic index of colonic mucosa epithelium to each rat plotted against his respective vincristine blocking times.

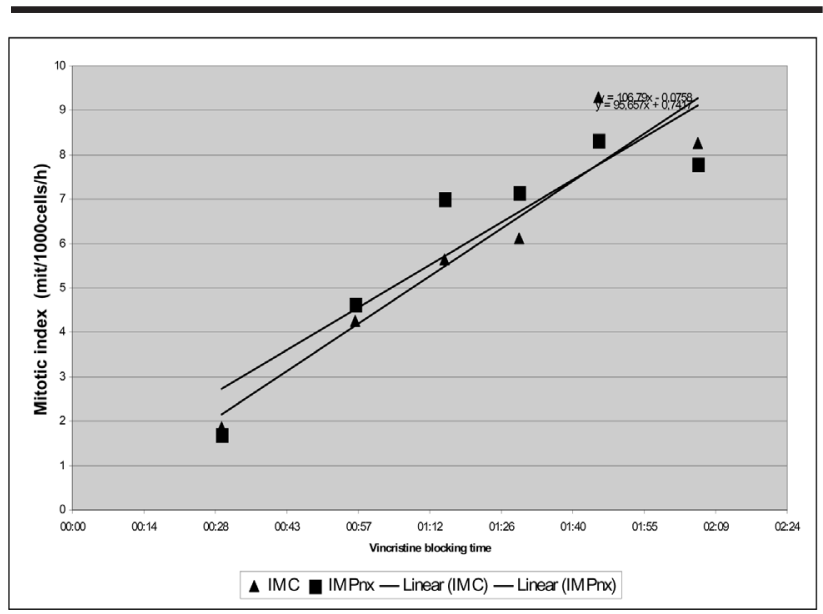

FIGURE 2 - Acute group mitotic index of jejunal mucosa epithelium from each rat, plotted against their respective vincristine blocking times.

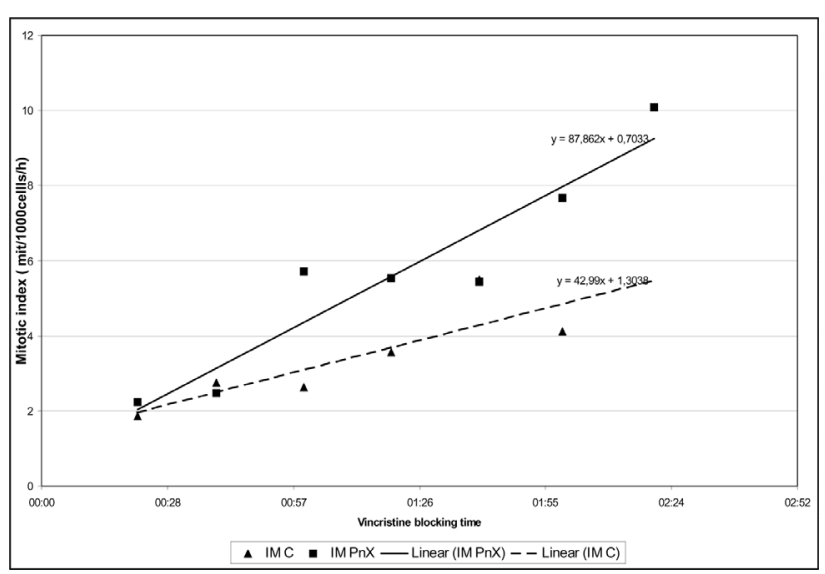

FIGURE 3 - Chronic group mitotic index of colonic mucosa epithelium from each rat, plotted against their respective vincristine blocking times. 


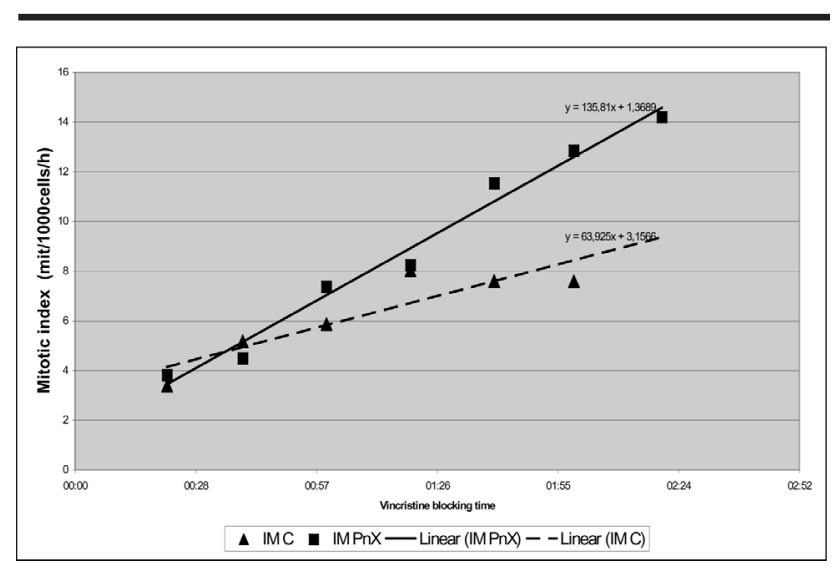

FIGURE 4 - Chronic group mitotic index of jejunal mucosa epithelium from each rat, plotted against their respective vincristine blocking times.
In Table 1, crypt cell population (CCP) and crypt cell production per crypt (CCPC) of colon in acute (15days) and chronic (90days) group are related. The results from proximal jejunum proliferation study are expressed in Table 2 .

Analyzing table 1 and table 2, we can note that $\mathrm{CCP}$ has not expressive variation between $\mathrm{C}$ and $\mathrm{PnX}$ groups. In chronic group, CCP also has not expressive changed, however CCPC has showed a significant statistical variation. As observed in tables, results are worth to both experiments (descending colon and proximal jejunum).

TABLE 1 - Effect of pinealectomy in new-born rats over crypt cells population (CCP) and crypt cell production per crypt (CCPC) of descending colon in both acute and chronic groups. The results showed were obtained using arithmetic mean \pm SEM (Standard Error Mean).

\begin{tabular}{|c|c|c|c|c|c|c|}
\hline \multirow[t]{2}{*}{ Group } & \multicolumn{3}{|c|}{ Crypt Cell Population } & \multicolumn{3}{|c|}{ Crypt Cell Population per Crypt* } \\
\hline & $\operatorname{Pn} X$ & Control & $p$ & $\operatorname{PnX}$ & Control & $p$ \\
\hline Acute & $58.77+/-1.77$ & $60.88+/-1.10$ & $>0.05$ & $24.92+/-4.82$ & $23.60+/-2.48$ & 0.24 \\
\hline Chronic & $107.61+/-5.58$ & $96.50+/-1.54$ & $>0.05$ & $37.78+/-2.22$ & $17.92+/-2.28$ & 0.027 \\
\hline
\end{tabular}

*metaphase cells $/ 1000$ cells per crypt per hour

$\mathrm{p}>0.05$ =significative

TABLE 2 - Effect of pinealectomy in new-born rats over crypt cells population (CCP) and crypt cell production per crypt (CCPC) of proximal jejunum in both acute and chronic groups. The results showed were obtained using arithmetic mean \pm SEM (Standard Error Mean).

\begin{tabular}{|c|c|c|c|c|c|c|}
\hline \multirow[t]{2}{*}{ Group } & \multicolumn{3}{|c|}{ Crypt Cell Population } & \multicolumn{3}{|c|}{ Crypt Cell Population per Crypt* } \\
\hline & $\operatorname{PnX}$ & Control & $p$ & $\operatorname{PnX}$ & Control & $p$ \\
\hline Acute & $31.56+/-0.45$ & $31.73+/-0.47$ & $>0.05$ & $39.92+/-3.49$ & $44.32+/-5.56$ & 0.35 \\
\hline Chronic & $70.21+/-1.94$ & $70.05+/-2.22$ & $>0.05$ & $57.54+/-2.19$ & $47.19+/-7.3$ & 0.005 \\
\hline
\end{tabular}

*metaphase cells /1000 cells per crypt per hour

$\mathrm{p}>0.05=$ significative

\section{Discussion}

Pinealectomy of new-born rats has not caused expressive alteration in cell proliferation and in crypt cell population, in acute group. However, in the chronic group we found an uprising crypt cell production per crypt in proximal jejunum, the same occurred in descending colon. Fifteen days aged rats do not have its optical tract pathways fully mature and mielinized yet. Once optical tract pathways integrity and maturity are fundamental to physiological function of pineal gland ${ }^{5}$, we can infer that in this age the control made by this gland is also immature and less efficient, what justifies the results obtained. Another conceivable explanation for different degree of effect of pinealectomy in the small bowel and the colon may be that the effect is due to long standing changes in the local levels of a neurotransmitter that is more plentiful in the small bowel than in the colon may be that the effect is due to long standing changes in the local levels of a neurotransmitter that is more plentiful in the small bowel than in the colon, e.g, somatostatin ${ }^{6}$. However, there is no available experimental evidence that pinealectomy can effect the levels of these neurotransmitters. It is known that pinealectomy reduces the level of circulating melatonin by $80 \%{ }^{7}$ and that melatonin is not only produced by the pineal but it is also found in the gastrointestinal tract ${ }^{8}$. In fact, Menendez-Pelaez ${ }^{9}$ have suggested a dual system in which a basal melatonin synthesis occurs in peripheral tissues, e. g, small and large bowel, while the circadian rhythm of melatonin is provided by the pineal gland. Thus, after pinealectomy, it is conceivable that the reduction in the level of melatonin in the colon might be less than in the 
jejunum if they each individually produced different amounts of melatonin, e.g, if the colon produced relatively more melatonin than the small bowel. Melatonin production is relatively higher in the more proximal parts of the gastrointestinal tract ${ }^{10}$. We hypothetized three theoretical models for the action of pineal gland in the intestinal epithelium proliferation. They are presented in Figure 5 and described below.

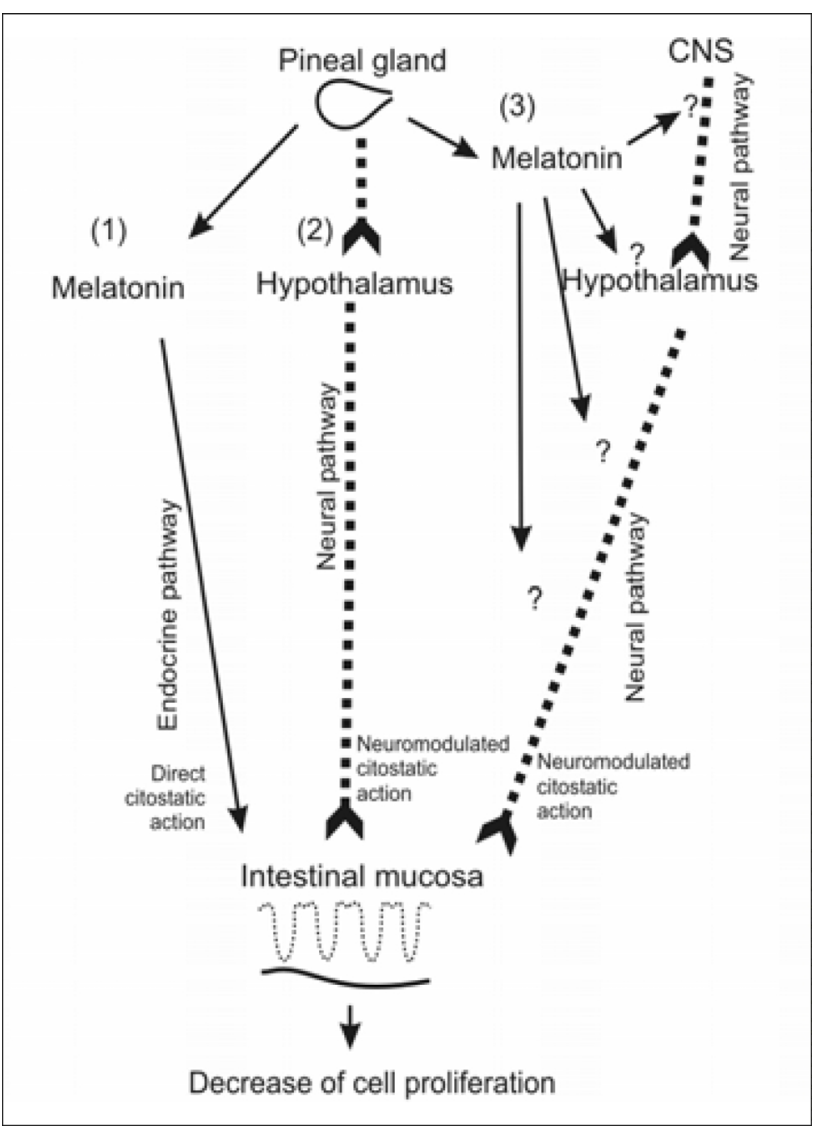

FIGURE 5 - Proposed mechanism to explain the effect of pineal gland in colonic and jejunal crypt cell proliferation control in rats. (1) Endocrinal action model, (2) Neural action model, (3) Combinated model

Model 1: Endocrine pathway - Plasmatic melatonin has endocrinal effect over colonic and jejunal mucosa cells, making direct citostatic action in cell proliferation. Pinealectomy leads to decrease in the plasmatic melatonin levels ${ }^{11}$. So, once in down levels, the citostatic effect of melatonin will not occur anymore, taking to an increasing cell proliferation. This model is believed by many authors. Melatonin has an inhibitory effect in jejunal and colonic epithelial cell proliferation of adult rats ${ }^{12}$. However, some researches deny this model. Intestinal neuroendocrinal cells also synthetize melatonin in a larger scale than pineal does ${ }^{13}$. This melatonin has a local action over mucosa cells. Melatonin levels in the gastrointestinal tract do not depend on pineal gland secretion, based on the fact that gastrointestinal melatonin levels do not change with pinealectomy ${ }^{11}$.
Model 2: Neural pathway - Pineal gland could have a modulatory effect over jejunal and colonic crypt cells through nervous connections not already described. The pineal gland citostatic effect probably follows this sequence: 1) Direct connections between hypothalamus and pineal gland, 2) Connections between hypothalamus and intestinal autonomic innervation, 3) Intestinal autonomic innervation influence on the activity of enteric plexus over crypt cell proliferation ${ }^{14}$. Supporting this hypothesis, is known that hypothalamus injuries are related to significant intestinal mucosa cell proliferation increase, what leads to conclude that these changes are not worth to functional alterations in the endocrinal system ${ }^{15}$. So, an important portion of this physiological pathway is eliminated, acting the same way as a hypothalamous injury, increasing intestinal cell proliferation.

Model 3: Combinated action - Putting together pros and cons from the two models set before, a unifying hypothesis for a role of both neural and endocrine systems to explain the pineal gland control over intestinal cell proliferation can be formulated. Central nervous system (CNS) has, through hypothalamus and autonomic nervous system, an important role in control of jejunal and colonic mucosa cell proliferation. An example for that is the decrease of distal colon tumor incidence when denervated by benzalkonium chloride (BAC) ${ }^{16}$. The melatonin released in plasma by pineal gland has an inhibitory modulator neuroendocrinal role in some place of nervous connection linking CNS and intestinal mucosa. Thus, pinealectomy promotes decreasing melatonin plasmatic levels, priving the nervous pathway from its inhibitory control, leading to an intestinal cell proliferation increase. Some additional considerations can be done about the neural pathway and the combinated action. Some organs of the human body have close relations with other. Neural processes of the hipothalamic nuclei can terminate on fenestrated vessels of the portal venous system that carries factors to the anterior lobe of pituitary hormones. There isn't descripition of any similar device that provides priority to any region of the nervous system by melatonin. On the other hand, there are connections between the pineal gland and hipothalamus ${ }^{17,18}$. In addition, either hypothalamus injuries ${ }^{15}$ or pinealectomy make to increase intestinal mucosa cell proliferation. These factors make the neural pathway specially attractive. As the increase of intestinal crypts epithelial cells is a carcinogenesis predetermining factor $^{19,20}$, the understanding of the interaction between pineal gland and this event has great importance. To turn this relationship clear, we intend to study these aspects following our research line on a brief future.

\section{References}

1. Kennaway DJ, Rowe SA. Controlled-release melatonin implants delay puberty in rats without altering melatonin rhythmicity. J Pineal Res. 1997;22:107-16.

2. Callaghan B. The long-term effect of pinealectomy on the crypts of the rat gastrointestinal tract. J Pineal Res. 1995; 18:191-6. 
3. Kuszak J, Rodin M. A new technique of pinealectomy for adult rats.

Experientia. 1977;33(2):283-4.

4. Tannock IF. A comparisson of the relatives efficiences of various mataphases arrest agents. Exp Cell Res. 1967;47:345-56.

5. Reiter RJ. The melatonin rhythm: both a clock and a calendar. Experientia. 1993;49:654-64.

6. Keast JR, Furness JB, Costa M. Somatostatin in human enteric nerves. Distribution and characterization. Cell Tissue Res. 1984;237(2):299-308.

7. Ozaki Y, Lynch HJ. Presence of melatonin in plasma and urine or pinealectomized rats. Endocrinology. 1976;99:641-4.

8. Bubenik GA. Localization of melatonin in the digestive tract of the rat. Effect of maturation, diurnal variation, melatonin treatment and pinealectomy. Horm Res. 1980;12(6):313-23.

9. Menendez-Pelaez A, Reiter RJ. Distribution of melatonin in mammalian tissues: the relative importance of nuclear versus cytosolic localization. J Pineal Res. 1993;15(2):59-69.

10. Huether G, Poeggeler B, Reimer A, George A. Effect of tryptophan administration on circulating melatonin levels in chicks and rats: evidence for stimulation of melatonin synthesis and release in the gastrointestinal tract.Life Sci. 1992; 51(12): 945-53.

11.Bubenik GA, Brown GM. Pinealectomy reduces the melatonin levels in the serum, but not in the gastrointestinal tract of rats. Biol Signals. 1997;6(1):40-4.
12. Lewinski A, Rybicka I, Wajs E, Szkudlimski M, Pawlikowski M. Influence of pineal indoleamines on mitotic activity of gastric and colonic epithelial cells in the rats: interaction with omeprazole. J Pineal Res. 1991;10:104-8.

13. Huether G. The contribution of extrapineal sites of melatonin synthesis to circulating melatonin level in higher vertebrates. Experientia. 1993;49:665-70.

14.Callaghan BD. The effect of pinealectomy and autonomic denervation on crypt cell proloferation in the rat small intestine. J Pineal Res. 1991;10:180-5.

15.Bindoni M, Bava A, Stanzani S. Mitotic rate in glandular tubules in small intestine after lesions at different loci of hypothalamus in the rat. IRCS. 1973;1:16.

16. Zucoloto S, Diaz JA, Oliveira JSM, Muccillo G, Sales Neto VN, Kajiwara JK. Effect of chemical ablation of myenteric neurones on intestinal cell proliferation. Cell Tissue Kinet. 1998;21:213-9.

17.Korf HW, Wagner V. Evidence for a nervous connection between the brain and the pineal organ in guinea pig. Cell Tissue Res. 1980;209:505-10.

18.Ariens-Kappers J, Smith RJ, Deries RAC. The mamalian pineal gland and its control of the hpothalamic activity. Prog Brain Res. 1974;41:149-74.

19. Menkin V. Celular injury in relation to proliferative and neoplasic response. Cancer Res. 1941;1:548-53.

20.Cohen BI, Raicht RF, Deschner EE, Takahashi M, Sarwal AN, Fazzini E. Effect of cholic acid feeding on N-metil-Nnitrosurea-induced colon tumors and cell kinetics in rats. J Natl Cancer Inst. 1980;64:573-8.

\section{Correspondence:}

Sérgio Britto Garcia

Department of Pathology, Ribeirão Preto Medical School

University of São Paulo

Av. Bandeirantes, 3900

14049900 Ribeirão Preto - SP - Brazil

Phone: (55 16)602-3180

Fax:(55 16)602-1068

sbgarcia@fmrp.usp.br.
Conflito de interesse: nenhum

Fonte de financiamento: nenhuma

Received: September 13, 2005

Review: October 19, 2005

Accepted: November 10, 2005

\section{How to cite this article:}

Dalio MB, Haikel Jr LF, Dalio RB, Pinto, APM, Silva JCF, Vespúcio MVO, Guimarães MA, Garcia SB. A study of the effects of pinealectomy on intestinal cell proleferation in infant newborn rats. Acta Cir Bras. [serial on the Internet] 2006 JanFeb;21(1). Available from URL: http://www.scielo.br/acb 